\title{
The Role of Migrant Associations in Adjustment, Integration and Social Development:
}

\author{
The Case of Nigerian Migrant Associations in Accra, Ghana ${ }^{18}$
}

\author{
Thomas Antwi Bosiakoh \\ Department of Sociology \\ University of Ghana, Legon \\ Accra, Ghana \\ Email:bosiakoh@gmail.com/bosiakoh@yahoo.com \\ DOI: http://dx.doi.org/10.4314/gjds.v8i2.5
}

\begin{abstract}
Different migration scholars have acknowledged the recent growth of migrant associations in different parts of the world. Though these associations are a worldwide phenomenon, existing literature draws mostly on those in the USA vis-a-vis, Latino migrants from Central and Latin America. In Ghana and Africa generally, literature on migrant associations is paltry. Those that exist only explore their development impacts on the migration sending areas. This paper discusses evidence from three Nigerian migrant associations regarding how they help members adjust and integrate in Ghana and their developmental impacts. The paper postulates that such social networks bind Nigerian migrants together in their new destinations and serve as substitutes for family relationships bonds. The associations play expert surrogate roles to ensure member adjustment and integration into Ghana. Though the associations are not direct vectors of economic development, their social activities make them useful social development agents in Ghana, their present location. Based on these, a policy case is made for the integration of migrant associations into Ghanaian migration policies.
\end{abstract}

Keywords: Migrant Associations, Social Networking, Adjustment, Integration, Social Policies

18 An earlier version of this paper titled 'Nigerian Migrant Association in Accra, Ghana: Their Role in Adjustment, Integration and Development' was presented at Session 605: Transnational Communities, Social Networks and International Migration of the 26th Conference of the International Union for the Scientific Study of Population (IUSSP) in Marrakech, Morocco (27 September to 2 October 2009). 


\section{Introduction}

Globalization in recent years has increasingly made migration one of the major forces shaping the world in the 21st century. Current estimates from the UN Population Division put migrant population to between 185-192 million, nearing the 200 million mark (IOM, 2005). Representing about three (3) per cent of the world's population, this figure is comparable to the 190 million combined population of Northern Europe, Southern Africa and the Caribbean (see the combined population of these regions from PRB, 2006). For this, and indeed many other reasons, migration literature is full of such descriptions as south-north and south-south migration streams. Mass migration has become one of the main global forces shaping the world in the 21st century.

In Africa, the dominant theme has been the movement to the developed west, although evidence suggests that intra-regional or intra-African migration dominates in the African migration (Antwi Bosiakoh, 2009; Awumbila, 2009). One corollary of increased migration which is already evident in the migration literature is the emergence and formation of migrant associations in the migration destination areas. However, despite the evidence of intra-regional or intra-African migration dominance in the general African migration, research attention on migrant associations has mainly focused on those of western countries such as in USA, Canada, the UK, Germany and The Netherlands, among others. African Diaspora in other African countries has rarely been the subject of serious study and consequently very little is known about them and their activities.

In this paper, I focus on this 'almost forgotten area' of African migration investigations - migrant associations - of one African country (Nigeria) in another African country (Ghana). The relevance of this paper is in its contribution to understanding intra-African migration with a focus on the associations embedded in the migration phenomenon. In doing so, I pose, among others the question of what benefit members of the associations derive from being members of the associations.

'When I first arrived in Accra, Ghana', one respondent answered with a serious look on the face, 'I didn't have any relative here. I also did not know anybody here. I was caught up in isolation and solitude. It was like I was 'home-sick', and I thought I would not be able to stay in Accra for long. I really missed home. Then at a live music reality show on one local television station, I met three Nigerians, a lady and two gentlemen. We became friends, and later, the two gentlemen introduced me to this association. Since then, members of this association have stood by me in every problem I have encountered'.

This observation reflects the view of one Nigerian migrant in Ghana whose stay in Accra probably would have been impossible but for the association he joined. For this Nigerian migrant, the association mollified the initial difficulties he encountered in his stay in 
Accra. He was lucky to have joined the Nigerian Committee of Brothers' Association. The Nigerian Committee of Brothers' Association is one of the three associations this paper focuses on. The others are the Nigerian Women's Association and the Edo State Association (also called the Edo Association). These associations are part of the estimated fifteen (15) migrant associations for about 2 million Nigerians in Ghana ${ }^{19}$. Members of these associations are part of the contemporary Nigerian migrants who continue to sustain the long history of Ghana-Nigerian relations (Antwi Bosiakoh, 2009) and radiate development impulses, particularly in Ghana.

Studies on migrant associations in West Africa initially portrayed the associations in terms of how they facilitated the West African urbanization process (Little, 1957) and the socio-cultural activities (Twumasi-Ankrah, 1995). In recent times, different aspects of Nigerian migrant associations in Accra have been explored with focus on their leadership and membership structures (Antwi Bosiakoh, 2010), as well as the benefits and entitlements embedded in the associations (Antwi Bosiakoh, undated). These associations operate under relatively durable organizational structures with well-defined tenures of leadership. Memberships of the associations are not large, ranging between a little over seventy (70) and above two hundred (200). The membership of the three associations indicate that, new migrants show higher leaning to the associations, but leadership responsibilities are mostly entrusted in the hands of older migrants (Antwi Bosiakoh, 2010). The benefits embedded in the associations are in the areas of health/medical, housing/accommodation, comfort and support in times of bereavement, socio-cultural benefits, and benefits specific to new arrivals and leaders (Antwi Bosiakoh, undated). While this paper deviates from all of these studies, it expands our understanding on migrant associations in (West) Africa in terms of their impacts on social development as well as their roles in the adjustment and integration efforts of their members in Accra, Ghana.

\section{Theoretical And Methodological Approach}

Studies on migrant adjustment and integration are often situated in assimilationist, adaptation and segregationist frames of analysis. For instance, Margaret Peil (1974) found both the segregationist and assimilationist arguments in her study of migrants in Ghana in the middle of the 1970s. Peil observed at one breadth that, the migrants resisted to be assimilated. In doing this, they employed a certain kind of residential segregation (often lived in separate part of towns known as Zongos), unique forms of social and political organization, and varying religious and cultural values to distinguish themselves from their Ghanaian hosts. In another breadth, Peil argued that, it was normal to find migrant farm labourers living in the same compound as their Ghanaian employers. In related study on Ghanaian immigrant associations in Toronto, Canada, Owusu (2000) argued that with its 'a priori' value judgment on desirable outcomes and ideological overtones, the assimilationist frame of analysis ought to be discarded. In place, Owusu suggested that

19 Conversation with a Minister at the Nigerian High Commission in Accra, Ghana on 26th March, 2008. 
adaptation stands as a more useful frame for understanding how Ghanaian immigrant associations in Toronto tried to integrate into the Canadian society. Earlier in 1996, Attah-Poku had worked on the survival and adjustment roles of Asanteman Ethnic Associations in New York and found that, though the adaptation framework was evident, the transnationalist view was more compelling. Upon careful consideration, this paper employs a mixed assimilation-adaptation kind of analytical frame. While feeding on adaptation as proposed by Owusu, the paper also leans on the assimilationist perspective evident in Peil's work. The aim here is to be as flexible as possible in the ways in which these theoretical viewpoints filter into the analysis of this paper. Integration of migrants, in the view of this paper, is better interpreted within the assimilationist frame, and for adjustment of migrants, the adaptation perspective appears stronger.

Data for this paper were generated from primary fieldwork employing multiple ethnographic methods of in-depth interviews, focus group discussions (FGDs) and informal discussions. The associations were selected based on two main factors, namely sex and types of the associations. Based on sex, there was one male association - the Nigerian Committee of Brothers' Association, one female association - the Nigerian Women's Association, and one mixed sex association - the Edo Association. These associations also depict three different types of associations, namely ethnic association (the Edo Association), national association (the Nigerian Women's Association) and a semblance of 'brotherhood' or charity association (the Nigerian Committee of Brothers' Association).

In-depth interviews were held with the association members and leaders. Seven (7) people each from the three (3) associations were interviewed. These aside, three executives, the chairman, the vice chairman, and secretary of two of the associations (Nigeria Committee of Brothers Association and Edo Association) were interviewed. In the case of the Nigerian Women Association, only the president and vice president were available for interview. All the informants were interviewed once, usually at their meeting grounds and in their homes during weekends or during evenings of weekdays. In some cases, agreements were reached to meet at a convenient spot. Each interview lasted for between one and one-andhalf hours.

In the case of Focus Group Discussions (FGDs) only association members were involved. For each association, one focus group discussion (FGD) was conducted with six (6) members. Topics that were discussed were generated from the in-depth interview questions for association members. Meetings of the associations were also observed over a five (5) month period to understand discussions that go into such meetings. Minutes and notes on a few previous meetings of the Nigerian Women's Association were also made available for study. In addition, the study benefitted from a few informal interactions with both association members and leaders. 


\section{Nigeria in Ghana: An Overview of Nigerian Presence in Ghana}

\section{Contextualizing Nigerian Migration to Ghana}

Evidence of intra-West African migratory movements reveals that Nigerian migration to Ghana dates back to the $15^{\text {th }}$ century (Antwi Bosiakoh, 2009; Rouch, 1954). Other studies trace the presence of Nigerians in Ghana to the early nineteenth century though their connection with the country goes as far back as the period of the caravan trade (Awumbila, Manuh, Quartey, Tagoe \& Antwi Bosiakoh, 2008; Anarfi, Kwankye, Ababio \& Tiemoko, 2003). Also, as shown in Table 1, as far back as the 1920s, Nigerian migration to Ghana was significantly high. Consequently, Twum-Baah (2005) observes that Nigerians are major participants in Ghanaian international migration. According to Manuh (2006), the total number of Nigerians in Ghana stood at 8,891 in 1999. This figure increased to 28,489 in year 2000 before peaking at 44,929 in 2001. It ho wever, plummeted to 24,718 in 2002 . Currently, the Nigerian High Commission puts the number of Nigerians in Ghana at over two million (see Antwi Bosiakoh, 2009).

Table 1: Foreign Africans in Ghana by Origin: 1921, 1931 \& 1960 Census Years (ooos)

\begin{tabular}{|c|c|c|c|}
\hline COUNTRY & $\mathbf{1 9 2 1}$ & $\mathbf{1 9 3 1}$ & $\mathbf{1 9 6 0}$ \\
\hline Dahomey (Benin) & - & - & 31.6 \\
\hline Ivory Coast & - & - & 54.4 \\
\hline Liberia & 12.6 & 6.8 & 8.7 \\
\hline Mali & - & - & 19.4 \\
\hline Niger & - & - & 24.9 \\
\hline Nigeria & 21.2 & 67.7 & 190.8 \\
\hline Togo & - & - & 280.6 \\
\hline Upper Volta & - & - & 194.6 \\
\hline Other West Africans & 14.5 & 199.1 & 6 \\
\hline Other Africans & - & 15.6 & 0.7 \\
\hline TOTAL & $\mathbf{4 8 . 6}$ & $\mathbf{2 8 9 . 2}$ & $\mathbf{8 1 1 . 7}$ \\
\hline
\end{tabular}

Source: Kay and Hymer, 1972

By the second quarter of the twentieth century, Nigerians constituted the largest single group (96\%) of the 70, 536 immigrants from other British West African colonies resident in Ghana (Cardinall, 1931). For this period, Adepoju (2005a) observes that Ghana's relative affluence made her the 'gold coast' for thousands of immigrants from West 
Africa, particularly Nigeria, Togo and Burkina Faso. The Biafran War that occurred after Nigeria's independence also led to the dispersal of a number of Nigerians across the world. In Ghana, Nigerians were particularly involved in mining diamonds and selling yam and meat as well as formed a part of the many foreigners who occupied key positions of economic dominance in trade and commerce in the country (Peil, 1974). The Yoruba and Hausa traders (Nigerians) in Ghana, for instance, controlled the market place, while other foreigners occupied many skilled positions in industry (Gould, 1974). Nigerians were the dominant group of people in the waterfront stores at Winneba, and the Fadama Autoparts Market in Accra (Stepleton, 1979). Also, about 40 per cent of female vendors in the Kumasi market were Yoruba (Skinner, 1960).

In responding to this dominance of the Ghanaian economy, foreigners were accused of posing a threat to the economic survival of the country (Adomako-Sarfoh, 1974). ${ }^{20}$ Consequent to these, the Aliens Compliance Order of November 1969 was promulgated, requiring all aliens in Ghana to be in possession of a residence permit if they did not already have one or to obtain it within two weeks. The Order affected most of Ghana's immediate neighbours - Ivory Coast, Burkina Faso and Togolese nationals (Antwi Bosiakoh, 2009; Awumbila, Manuh, Quartey, Antwi Bosiakoh, and Tagoe, 2011). In the words of Hundsalz (1972) however, majority of the Order's victims were traders of the Yoruba ethnic group from Nigeria (cf. Gould, 1974; see also Brydon, 1985). The expulsion affected over 100,000 aliens (Gould, 1974).

\section{From Immigration to Emigration Statuses: The Case of Ghana and Nigeria}

After the devastation of the Biafran War in the 1970s, Nigeria's economic position improved (Brydon, 1985). Boom in that country's oil industry spawned abundant jobs (Adepoju, 1984). As a result, Nigerians developed disinterest in emigration because local working circumstances became attractive. The attendant prospects of rising incomes and rapid industrialisation exerted pull on a number of West African labour migrants (Haas, 2006) especially those from Ghana, thereby making Nigeria an important migrant receiving country, and also complete a reverse migration transition process from a net emigration country to a net immigration country. Statistics in the early 1980s put the average number of Ghanaians who migrated into Nigeria to 300 per day and in December 1980 an estimated 150,000 Ghanaians had registered with the Ghana High Commission in Lagos (Anarfi, 1982, cf. Anarfi, et al 2003:7). Following Nigeria's oil-led economic prosperity, the country was thrown into economic restructuring and a sharp decline in oil revenue. The results of these were evident in the decline of living and working conditions, wage freeze, devalued national currency, and declining real incomes (Adepoju, 2005a). These conditions fuelled large-scale emigration, driving several professionals to sell their skills internationally. This made Nigeria undergo her second migration transition process,

20 The economic malaise and the fact that aliens became scapegoats constituted popular press outputs, see for example Brydon, 1985 for some details. 
this time from a net immigration country to a net emigration country (Antwi Bosiakoh, 2009).

Over time, Ghanaian migrants in Nigeria were blamed for economic and political challenges that confronted the Nigerian government. They also became first count scapegoats and targets of hostility from the native population (Adepoju 1984, 2005b; Brydon, 1985; Peil, 1974), a situation that Gravil has described as a 'mere self-righteous opportunism' (Gravil, 1985:529). Ghanaians were cited for being responsible for the then flourishing criminal activities in that country (Gravil, 1985:532). In early 1983, the Shagariled Government of Nigeria revoked the ECOWAS Protocol on free movement of persons to expel, just as Ghana did to Nigerians in the late 196os, about 1 million Ghanaians (Arthur 1991; Adepoju, 2005a). In June 1985, about 0.2 million illegal aliens were again expelled as Nigeria's economic crisis deepened following the implementation of structural adjustment programme (Adepoju, 2005a:32). According to Brydon, the official estimate for dispelled Ghanaians from Nigeria is somewhere in the range of 900,000 to 1.2 million ${ }^{21}$.

\section{Recent Developments in Nigerian Migration to Ghana}

In the immediate post-independence era, Ghana continued to attract a number of migrants from the West African sub-region, thanks to her relative affluence at the time. This period generated a lot of empirical studies on migrants in Ghana ${ }^{22}$. In the recent past however, the number of studies on Ghana's immigrant status seems to have dwindled, due perhaps to the poor socio-economic and political situation of the country especially in the 1980 s and early 1990s, and the unattractive position the country occupied in the eyes of migrants. Indeed these periods also saw a lot of out migration by Ghanaians to places within and outside West Africa and Africa. Nigeria, Ivory Coast, Sierra Leone, Liberia, South Africa, Britain, and USA are but a few of such destinations.

Since 1992, there has been a growing desire by Ghanaians towards democratic governance. This undoubtedly has paid off. The country has enjoyed relative peace as compared to her neighbouring nations. Two of Ghana's immediate neighbours - Togo and the Ivory Coast - experienced turmoil during the time under review. It was within this period that several West African countries experienced political upheavals ${ }^{23}$. In these unstable situations, Ghana played a peace advocate's role. The country was a sanctuary of peace in an area described variously as one of the 'most unstable' regions in the world. The country's economy is flourishing and is about the most stable in West Africa. The economic and

\footnotetext{
21 Brydon gives detailed composition of official estimate for dispelled Ghanaians from Nigeria.

22 A classic example of these studies is Margaret Peil's 'Ghana's Aliens'. International Migration Review, Vol. 8, No.3, International Migration in Tropical Africa. pp. 367-381. See also Beals R. E. and R. E. Menezes (1970). 'Migrant Labour and Agricultural Output in Ghana', Oxford Economic Papers 22(CD): 109-27.

23 Liberia, Nigeria and Sierra Leone best exemplify this situation.
} 
political systems show stability ${ }^{24}$. Various democratic structures are firmly established in the country (Antwi Bosiakoh, 2009). In addition, five democratic elections have been held, the last in 2008, which stretched the democratic elasticity of the country to its limit. The general aspiration of the populace is that of a country entrenched in democratic tradition. Consequent to these, the country has experienced widespread immigration, mostly from the West African sub-region, and Nigeria in particular.

The banking and insurance sectors in Ghana have for instance experienced mergers, takeovers and new entrants in recent years. These have largely been influenced by Nigerians following, in the case of the banking sector, the Nigerian Central Bank's Recapitalisation Policy. The Policy was intended to spur on a consolidation of the then overcrowded banking sector of Nigeria, mainly through mergers to reduce the number of banks from close to one hundred (100) to just about a dozen. In addition, Nigeria's mobile communication giant, Globacom secured license in June 2008 to operate as Ghana's sixth mobile communication operator (Antwi Bosiakoh, 2009). Nigerian students also form part of the bulk guests at the admission offices of many Ghanaian universities, visiting and calling daily to make inquiries on admission and transfer requirements. They constitute the largest proportion of foreign students of Ghana's universities (University of Ghana, 2004; 2005).

For migrants in general, the obstacles encountered upon arrival in a destination and during the process of integration influence the way they organise their actions. Stripped of the presence of family members, other friendship associations emerge, and the dynamics of social relationships and their underlying cultural ethos surface (Meier, 2005:55-56). Migrants in these situations create social networks to facilitate their settling processes and their incorporation into the host society (López et. al 2001; Massey, Arango, Hugo, Kouaouci, Pellegrino \& Taylor, 2005). In the process, these social networks give way to formal structures like migrant associations to meet their needs. The three Nigerian migrant associations conform to this.

\section{Nigerian Migrant Associations in Accra, Ghana}

\section{Profiles and Formation Histories of the Associations}

According to some studies (see for example Pojmann, 2007; López, Escala-Rabadan and Hinojosa-Ojeda, 2001), migrants create informal social networks in their settling process. To a large extent, these social networks give way to migrant associations. Migrant associations are therefore the formal manifestations of migrant social networks (López et al., 2001). This assertion is supported by Owusu (2000) who observes that migrants, soon after arriving in their destination, organize themselves in associational form. For the three Nigerian migrant associations in Accra - Ghana, the observations by López et

24 This observation is in comparison to Ghana's West African neighbours including Liberia, Cote D’Ivoire, Sierra Leone, Togo Benin, Nigeria et cetera. 
al (2001) and Owusu (2000) appear to be accurate representations of their formation histories. Although Nigerians have been in Ghana for a long period, the associations under this study started only in the early years of the first decade of this century. The timing of the formation of these associations was influenced by the recent influx of Nigerians into Ghana, which, according to Antwi Bosiakoh (2009) was informed by the relative peace and stability in Ghana. Interviews and focus group discussions with leaders and members of the associations showed that, it is these factors that provided viable platform for the formation of the associations.

\section{The Nigerian Women's Association (NWA)}

The NWA, an all-female association, was formed in 2001 at the Banquet Hall, Accra. Its inauguration was done by the then First Lady of Ghana, Mrs. Theresa Kuffour in the presence of some officials of the Nigerian High Commission in Ghana. The NWA constitutes a revitalized version of a previously existing association. The previous association collapsed because of inactivity. Later on in the later part of the 199os, there developed an awareness of the growing numbers of Nigerian women in Accra. It was this awareness that gave rise to a desire of this category of Nigerian migrants to establish and maintain ties with one another through formal association.

Prior to the formation of the Association, the women formed friendship networks based on common citizenship. Under this common factor however was the fact that, as women migrants, there was the need to form a distinctive association that would deal with their peculiar problems. They were aware of their unique position as women, the peculiar challenges they faced and the absence of state-led institutional bodies in Ghana to assist them.

The NWA draws its membership largely from among Nigerian women based in Accra. Though it is an all-female association, it allows men to be part of its activities. It currently has a membership size of 100. Its activities are mostly in charity and philanthropy. Children occupy a central place in the activities of the NWA. The association meets once in a month, on Saturdays.

\section{The Nigerian Committee of Brothers' Association (NCBA)}

Unlike the NWA, the NCBA is an all-male Nigerian association in all of Ghana. The association was formed in 2004, with the objective to bring together, all Nigerian brothers in Ghana and monitor each brother's activity to create a good image of Nigeria in Ghana. Like the NWA, the formation history of this association was due to the realization of the 
growing numbers of Nigerians in Accra, Ghana. There developed at this time the need to form associations to deal with the problems they encountered in Accra, Ghana. It is therefore accurate to argue, just as some scholars have done, that migrant associations are formed to take care of the problems migrants face in their destinations (López et. al 2001; Owusu, 2000; Jenkins, 1988; Okamura, 1983; Sardinha, undated).

The NCBA meets every fortnight, on Sundays, and has membership strength of over two hundred (200) people. Membership of the association is based on sex (males) and citizenship (Nigerian). Ethnicity does not play a part in considerations for membership. In spite of its national coverage, most of the members of the NCBA reside at Madina and Adenta suburbs of Accra. The Association's greeting which has become its motto begins with 'Committee' and the response 'Brothers'. This is repeated three times.

\section{The Edo State Association (ESA)}

The ESA, also called the Edo Association, in Ghana is the youngest of the three associations under study. Located at Abeka Lapaz, a suburb of Accra, this association was formed in 2006 in Accra, following discussions by three people from the Edo State of Nigeria. Edo is one of the numerous ethnic nationalities and administrative states in Nigeria. The Edo people occupy the old Bini Province of the Western Region of Nigeria. The Edo State is currently a state in the Federal Republic of Nigeria with Benin City as its capital. The Edo State Association in Ghana is just one of the many Edo State Associations around the world. There are chapters in Europe, specifically in Italy and Britain, just to mention a few. There is a US Chapter and in West Africa, branches exist not only in Ghana, but also Togo and Benin. Edo Global Organization (EGO) is the umbrella organization for all Edo people in the diaspora ${ }^{25}$.

The ESA in Ghana meets every fortnight on Saturdays. It has membership strength of seventy-five (75) people. To be a member of the Edo Association requires that, one comes from the Edo State in Nigeria and resident in Accra, Ghana. Among other things, this association can be described as an ethnic association, unlike the NWA and the NCBA which are national in orientation. In addition, this association, unlike the other two associations is a mixed sex association.

\section{Activities of Nigerian Migrant Associations in Accra}

The activities of the three Nigerian Associations vary greatly. This variation can be explained with reference to the reasons underlining their formations.

25 The Edo Global Organization prides itself as a non - partisan, non - governmental, voluntary organization for unifying and actualising the yearnings of Edo in Diaspora in transforming Edo Land into a paradise through hard work, excellent management of available resources, self-help development projects, accountability and good governance. Details of the Edo Global Organization are available at: http://edoglobalorganization.org/ 
Thomas Antwi Bosiakoh

The Role of Migrant Associations in Adjustment, Integration and Social Development:

\section{The Nigerian Women's Association (NWA)}

Much of the activities of the NWA are in social development, particularly in the area of child development, charity works and mother care services. During such meetings, members discuss activities that took place in the previous month. These activities include visits to children's homes (orphanages), donations to social welfare institutions, food and/or fashion fairs, and children's parties, among others. The Association organizes parties for children every Independence Day celebration in Ghana. During such events, children are drawn from orphanages and other motherless baby homes to mingle and interact with children of association members. Music of both Ghanaian and Nigerian origins are played to entertain the children and association members.

Since children occupy a special place in the affairs of this association, frequent visits are paid to orphanages in Accra, Tema and Nsawam. Other activities of the association include visits to prisons, particularly the Nsawam medium security prison, peace walks, food and fashion fairs, home Keeping seminars and resolution of personal, marital and family disputes. These activities of the NWA are meant to promote social interactions. But the Association does more than promoting social interaction among members. The Association is aware of the difficulties that members, both new and old encounter. These problems are mainly in the area of housing. In response to this therefore, the Association helps members to locate available housing vacancies in Accra for its members. Members of the Association acting through their leaders also engage with landlords and do the rent rate negotiations on behalf of the would-be migrant tenants. In addition, the association provides initial advance payment, particularly for new comers to help in their transition and incorporation into the Ghanaian society.

\section{The Nigerian Committee of Brothers Association}

The NCBA serves as a vital source of financial assistance for its members. It offers direct interest-free financial assistance (also described as 'soft loans') to its members with flexible repayment terms. In interacting with the members of this association, it became clear that, a number of them had benefited from the association's 'soft loan' facility. Indeed older members experiencing financial difficulties had also turned to the association for this facility. In most cases, members accessed this facility to take care of housing and accommodation problems, but others used it to offset medicare (hospital) bills. There were a few others who used the facility to strengthen their businesses. In addition, the NCBA organizes social and charity-related activities to promote 'social intercourse' and socially induced interactions among its members. These activities include End of Year Parties, congratulatory parties, and visits to orphanages and hospitals. In most cases, visits are accompanied with donations. When a member acquires a new house or vehicle, congratulatory party is organized in his honour and also to inaugurate the house or vehicle their 'own way'. Similarly, parties are organized for newly married members as well as members who give birth. 


\section{The Edo State Association}

The activities of the ESA in Accra, Ghana show differences and similarities to the activities of the other associations. As an ethnic association, members of the Edo Association rely on the association not only for emotional support, but also financial assistance. Members who have a new baby receive financial and material support from the association. Here in the Edo Association, material and financial support to members come in the form of donations. Members donate generously with the hope that, similar donations would be made to them should they face difficulties in the future. During child-naming and/or child christening ceremonies, during marriages, among others, donations are made to the person(s) concerned. These donations demonstrate not only the economic and social value of the association, but also the cultural significance attached to marriage and child births in the Nigerian society. The Edo Association also helps to resolve personal and marital disputes between its members, as well as between members and their Ghanaian host.

\section{Adjustment and Integration During Migration}

Migrants are often isolated in their host communities. They also face cultural and language barriers, lack confidence and are not always aware of opportunities available to them. In addition, most migrants find the initial phases of their migration difficult especially when the requisite networks for participating in mainstream socio-economic activities in the country of settlement are not yet in place (Caglar, 2006). In simple terms, migrants face integration problems, and for new arrivals, the problem is compounded by adjustment difficulties. Along these lines, migrant associations have been treated in functional terms (Owusu, 20oo; Attah-Poku, 1996; Okamura, 1983; Little, 1957).

\section{Adjustment and Integration Roles of the Nigerian Migrant Associations}

For new Nigerian migrants, the associations help integrate them into the Nigerian community in Accra, and the general Ghanaian society. The Associations do this by encouraging them to be active participants in the associations, and by creating a series of networks to represent their interests and meet their needs. These networks also enable the new migrants to voice their concerns. The ESA, for instance, helps new members deal with the problems they encounter with immigration officials. The NCBA also takes special interest in the initial settling problems that members encounter, especially those that relate to accommodation.

The activities of the associations also help new migrants to adapt and integrate into the Ghanaian society. In the special case of outdoor activities, the new arrivals become acquainted with their new 'sociological universe' as they continue to fine-tune, with what one respondent indicated as 'the new social space, Accra'. In most cases, the Associations give advice to newly arrived migrants to attend association activities to ward off loneliness which often characterizes the lives of migrants in the initial phase of 
their adjustment process. By virtue of these activities, the Associations can be conceived to serve as substitutes for migrants' extended families in Nigeria, allowing new migrants to be 'at home away from home'. The Associations therefore contribute to 'out of home home-making' or better still, 'home-making abroad' by Nigerians. The Associations also encourage their members to take full part in the life of the neighbourhoods within which they find themselves. The members are especially encouraged to be part of communal activities or local community works and to exhibit high level civic spirits in order to promote integration and cohesion in the communities where they reside.

Some members of the Associations are also encouraged to join in prayers with locals in local churches and mosques. For those who accept to join churches, the various Nigerian churches in Accra become, in most cases, the first point of real integration, with both Nigerians and Ghanaians. Here, they come into contact with many Nigerians and Ghanaians. While some of them forge friendship networks, others develop acquaintances. For others, this is a platform for real interactions and interrelations for forging strong connections to deal with the adjustment and integration difficulties they encounter.

\section{Socio-Economic and Cultural Dimensions of Adjustment}

The reasons and activities of the three Nigerian Associations, it has been observed, vary greatly. In economic terms, the associations serve as vital sources of financial assistance for members. Members depend on their association for soft loans and solution to other economic difficulties they encounter. Though evidence of associations providing information on jobs to members was not found, it was clear some of the services that the associations provide enhance the economic activities of members.

A number of Nigerians in Ghana engage in trading activities, and from time to time, they encounter problems with the Ghanaian Customs and Police officials. Some of these problems end up in law courts. But when they occur, Associations offer assistance by intervening to find solution on behalf of the troubling member, even if it means finding legal counsel for him or her. These activities and services enhance the economic activities of members, and for some focus group discussants, the economic-related activities of their Associations '...remain outstanding, unmatched by any other activity'. But more economic activities remain to be done. The NCBA intends establishing a transportation business to generate funds for other projects and also to offer employment to some of its members. In a similar vein, the NWA hopes to set up a viable economic venture to provide jobs for some of its members.

The subject of cultural integration has been sparingly dealt with in the earlier sections of this paper. Here, it is important to point out that the associations work to ensure that their members continue to be in touch with the Nigerian culture, while they still find ingenious ways to integrate/assimilate into the broader Ghanaian cultural landscape. Nigerian cultural manifestations are glamorous in several ways. They are also unique and a source of pride to many Nigerians in particular and Africans in general. As such, 
the associations try to prevent it from sliding from the lives of their members. Members are encouraged to show pride in their culture. Leadership of the associations indicated that, 'culture is our lives, we should not kill it rather we should sustain it'. In line with this, the associations sustain the culture of their members through several socio-cultural activities. Members are encouraged to express, promote, and preserve their traditional songs and dances as well as dresses and food menus - activities which both membership and leadership acknowledged, give the distinctive character and appearance of them as Nigerians.

For the Edo people, in particular, and indeed all of Nigerians in general, traditions occupy the apogee of their way of life (Aluede and Braimah, 2005). As such marriages and childnaming and/or christening ceremonies prop up display of Nigerian culture. Other cultural manifestations characterize funerals, parties, and independence cerebrations. These activities have cultural importance, as they draw large number of people, both Nigerians and Ghanaians, together amidst cultural manifestations. In the special case of funerals, mourners and the bereaved members exhibit culture, tradition and heritage. The cultural activities unite members as they portray Nigerian culture together, and also build their self-esteem. The unity and confidence that such cultural activities engender help the associations and their members to mobilize resources and pool their energies together to deal with the challenges they face in Ghana. Association members are constantly reminded of their root. They are also encouraged to form friendship networks and forge understanding among members. In addition, members are encouraged to promote the speaking of Nigerian languages and teaching them to their children. The President of ESA, for instance, intimated that, 'teaching Nigerian language or languages to our children does not interfere with their grasp of a second language or even a third language'. In simple terms then, the associations play vital roles in the lives of their members. These roles are socially and culturally relevant for members. They help members to adjust, adapt and integrate into Accra.

\section{Nigerian Migrant Associations as Vectors of Social Development?}

The impact of migrant associations on development is an issue many studies have explored (Orozco \& Rouse, 2007; Portès et al., 2007; Babcock, 2006; Beauchemin and Schoumaker, nd; Caglar, 2006; Orozco, 2006; Silva, 2006; Akologo, 2005). No conclusive findings however have been reached yet. Some studies acknowledge the presence and activities of migrant associations to constitute a powerful force for development. Such studies conceive migrant associations as 'faithful' development intermediary actors, and therefore form inventive working networks with Non-Governmental Organizations (Akologo, 2005; Orozco \& Rouse, 2007; Portes, et al., 2007). There are other studies that conclude that migrant associations are not growth machines, not even growth poles. These positions are treated for their merits, and in this scientific endeavour, contextual specificity and relativity is paramount. 
In this paper, it is difficult to identify elements of economic development in the activities of Nigerian migrant associations. But giving the economic undertone in the migration decision-making (see Antwi Bosiakoh, 2009: 105), and more especially the recent influx of Nigerian banking and insurance companies in Ghana, Nigerian migration generally may have some economic development impact on the economy of both Ghana and Nigeria. This, however, cannot be said of the activities of the migrant associations. The development activities of Nigerian migrant associations are more in charity and philanthropy in Ghana. Social service activities far outweigh other economic development considerations. These activities are socially relevant and therefore in line with 'social development'. Charity and philanthropy to orphans, child care institutions, prisons and hospitals appear very much compelling in the activities of the associations. While association donations to hospitals help improve health services delivery in Ghana, those to orphanages and prisons assist in improving the standard of living of both prison inmates and orphans.

Two of the migrant Associations - the NCBA and the NWA - however nurse future intentions to establish transportation businesses and other viable economic ventures respectively. Giving these intentions, one can expect more positive roles of the Associations in the economic life of the members, and therefore more economic development impact of the associations in Ghana, and possibly in Nigeria. Giving also the ages of the associations (the oldest being 8 years), one could expect the associations to expand their scope of activities to include other economic development activities in the future. The associations have settled on social activities at their 'embryonic phase'. In the course of time, as this embryonic phase gives way to a more broadened outlook, the associations may turn to more economically and probably politically related activities for as argued by Sardinha (undated), when migrant associations broaden their outlooks, it calls for a complete change in goals and objectives as well as activities. These are extrapolations though, and must be treated in futuristic terms barring all impediments to the realization of present intents.

For now, most of the benefits of the activities of the Associations are available only in Ghana and not in Nigeria. This is because all the activities are undertaken in Ghana with the intended beneficiaries being Ghanaians. The Associations have not expanded enough to make visible impacts in Nigeria. It is only the remittances of Association members that benefit Nigeria, and since these remittances are individual initiatives (not group remittances), they do not feature in the associations' beneficial development activities to Nigeria. However, there are a number of activities by Nigerians in Ghana that also impact positively on both the Nigerian and Ghanaian economies. The influx of Nigerian banks and insurance companies, not to mention various forms of movie industry and communication activities also radiate development impulses that benefit both Ghana and Nigeria (Antwi Bosiakoh, 2009). Are Nigerians in Ghana vectors of development in Ghana and Nigeria? This is not a question to be answered with a straight forward response. While activities of Nigerian migrants outside their associations may have some positive economic development implications for Ghana and Nigeria, the associations explored in 
this paper are not direct vectors of economic development. However, their social activities (charity and philanthropic) make them useful social development agents in Ghana.

\section{Summary and Policy Implications}

The discussions in this paper show that, Nigerian migration to Ghana has a long history, dating back to the caravan and pre-colonial times. This long history connects the contemporary type of Nigerian migration to those in the past (Antwi Bosiakoh, 2008; 2009), a situation which has given rise to various dynamics within the Ghanaian society. In this study, the argument has been that, the associations were formed soon after members arrived in Ghana to meet their various needs as migrants. The obstacles that these migrants encountered upon arrival in Ghana and during the process of integration influenced the way they organised their actions.

In the process, social networks and friendship relations gave rise to the emergence of these migrant associations in Accra, Ghana. While the NWA reflects both gender-related needs of the migrants (a kind of sisterhood), the NCBA exudes brotherhood sentiments. It is the ESA that blends the two extremes; this association is ethnic based. Taken together, these associations service their members in the area of adjustment, particularly new arrivals, as well as migrant integration into the Ghanaian society. In doing these, the associations engage in all manner of activities, reflecting both manifest and latent reasons for their establishment. And though most of the activities are socio-cultural in orientation, they nonetheless have some economic bearings. The activities of the associations cannot be considered in any direct way as vectors of economic development; they are rather useful social development intermediaries in Ghana.

What does all this imply for Ghanaian migration policy planning? Some existing studies in Ghana suggest that, with the current socio-economic, political and security issues in Ghana and Nigeria, it is quite unlikely for Nigerian migration to Ghana to ease, at least not in the near future. Even with cautious extrapolations, there is the possibility that Nigerian migration to Ghana would increase in volume, thanks to the oil discovery, political stability, historical connection as well as the similarity in cultures between the two countries and among their peoples (Antwi Bosiakoh, 2008; 2009). Expulsion measures as those employed by Ghana in the late 196os and Nigeria in the early 1980s are clearly not the option for Ghana at this time. The option for Ghana is to maximize the benefits of this migratory phenomenon. Part of the benefits of this migratory movement is in the activities of what associations of this kind may engender. In addition, migration policy formulation in Ghana has to consider incorporation of migrant associations into the broad migration policy framework because of the control that these associations have over their members. Through this, attempts at mobilizing migrants for economic reason, conflict resolution reason, among others could be directed at the associations. 


\section{References}

Adamako-Sarfoh, J. (1974). The Effects of the Expulsion of Migrant Workers on Ghana's Economy, with Particular Reference to the Cocoa Industry. In S. Amin (Ed.) Modern Migrations in Western Africa. London: Oxford University Press.

Adepoju, A. (2005b). Migration in West Africa. Paper prepared for the Policy Analysis and Research Programme of the Global Commission on International Migration. Available at www.gcim.org (2005a). Patterns of Migration in West Africa. In T. Manuh (ed.) At Home in the World?: International Migration and Development in Contemporary Ghana and West Africa. Accra: Sub-Saharan Publishers.

(1984). Illegals and Expulsion in Africa: The Nigerian Experience. International Migration Review. Vol. 18, No. 3, Special Issue: Irregular Migration: An International Perspective, pp. 426-436.

Akologo, S. Z. (2005). The Role of Diaspora-Based Organizations in Socio-economic Development at the Local Level in Ghana. In T. Manuh (ed.) At Home in the World? International Migration and Development in Contemporary Ghana and West Africa. Accra: Sub-Saharan Publishers.

Aluede, C. O. and A. A. Braimah (2005). Edo Folk Songs as Sources of Historical Reconstruction. Studies on Tribes, Vol. 3, No. 2:123-128.

Anarfi, John, Stephen Kwankye, Ofosu-Mensah Ababio and Richmond Tiemoko (2003). Migration from and to Ghana: A Background Paper. Working Paper C4, Development Research Centre on Migration, Globalisation and Poverty.

Anarfi, J. K. (1982). International Labour Migration in West Africa: A Case Study of the Ghanaian Migrants in Lagos, Nigeria. M. A. Dissertation, Regional Institute for Population Studies: University of Ghana Legon-Accra.

Antwi Bosiakoh, Thomas (undated). In the Name of 'Unity is Strength': Exploring the Benefits and Entitlements in Nigerian Migrant Associations in Accra, Ghana. (in review).

(2010). Leadership and Membership Structure of Migrant Associations: The Case of Nigerian Migrant Associations in Accra, Ghana. Journal of Social Sciences and Public Policy, Vol. 2, (September) pp. 37-51.

(2009). Understanding Migration Motivations in West Africa: The Case of Nigerians in Accra, Ghana. Legon Journal of Sociology, Vol. 3, No. 2. (Dec., 2006June, 2009), pp. 93-112. 
(2008). Understanding Ghana's Migrants: A Study of Nigerian Migrant Associations in Accra, Ghana. Unpublished Master of Philosophy Thesis submitted to the Department of Sociology, University of Ghana, Legon.

Arthur, J. A. (1991). International Labor Migration Patterns in West Africa. African Studies Review, Vol. 34, No. 3: 65-87.

Attah-Poku, Agyemang (1996). Asanteman Immigrant Ethnic Association: An Effective Tool for Immigrant Survival and Adjustment Problem Solution in New York City. Journal of Black Studies Vol. 27, No. 1:56-77.

Awumbila M. (2009). Intra-Regional Migration in West Africa: Changing Patterns and Dynamics.

\section{Development Issues, Vol. 11, No. 2:8-10.}

Awumbila, M., T. Manuh, P. Quartey, T. Antwi Bosiakoh \& C. A. Tagoe (2011). Migration and Mobility

in Ghana: Trends, Issues, and Emerging Research Gaps. Accra: Woeli Publishing Services.

(2008). Migration Country Paper - Ghana. Paper prepared under the McArthur Project, African Perspectives on Human Mobility Programme, International Migration Institute, Oxford.

Babcock, E. C. (2006). The Transformative Potential of Belizean Migrant Voluntary Associations in Chicago. International Migration Vol. 44, No. 1:31-53.

Beauchemin C. and B. Schoumaker (undated). Are Migrant Associations Actors in Local Development? A National Event-History Analysis in Rural Burkina Faso'. To be published as a working paper on: http://www.uclouvain.be/6913.html

Brydon, L. (1985). Ghanaian Responses to the Nigerian Expulsions of 1983. African Affairs, Vol. 84, No. 337, pp. 561-585.

Caglar, A. (2006). Hometown Associations, the Rescaling of State Spatiality and Migrant Grassroots Transnationalism. Global Networks, Vol. 6, No. 1:1-22.

\section{Cardinall, W. A. 1931. The Gold Coast. Accra.}

Gould, W. T. S. (1974). International Migration in Tropical Africa. International Migration Review, Vol. 8, No. 3:347-365.

Gravil, R. (1985). The Nigerian Aliens Expulsion Order of 1983. African Affairs, Vol. 84, No. 337: 523-537.

Haas, H. D. (2006). International Migration and National Development: Viewpoints and Policy Initiatives in Countries of Origin - The Case of Nigeria. Working paper Migration and Development series Report 6. A report prepared for Radboud 
University, Nijmegen and Directorate General for International Cooperation (DGIS), Ministry of Foreign Affairs the Netherlands.

Hundsalz, M. (1972). Die wanderung der Yoruba nach Ghana und ihre Ruckkehr nach Nigeria. Erdkunde, 26,218-230.

International Organization for Migration (2005). World Migration Report. International Organization for Migration (IOM)'s biennial flagship publication (No. 882 - 22 June 2005).

Jenkins, S. (1988). Ethnic Associations and the Welfare State. New York: Columbia University Press.

Kay, G. B. and Stephen Hymer (eds.) (1972). The Political Economy of Colonialism in Ghana: A Collection of Documents and Statistics (1900-1960). Cambridge: Cambridge University Press.

Little, Kenneth (1957). The Role of Voluntary Associations in West African Urbanization. American Anthropologist, UX (4).

López, F. H., L. Escala-Rabadan and R. Hinojosa-Ojeda (2001). Migrant Associations, Remittances, and Regional Development Between Los Angeles and Oaxaca, Mexico. Research Report Series No. 10. North American Integration and Development Center School of Public Policy and Social Research.

Manuh, T. (2006b). Ghana Migration Profile. A Consultancy Report for the Ministry of Finance and

\section{Economic Planning, Accra.}

Massey, D. S.; J. Arango; G. Hugo; A. Kouaouci; A. Pellegrino and J. E. Taylor (2005). Worlds in Motion: Understanding International Migration at the end of the Millennium. Oxford: Oxford University Press.

Meier, B. (2005). Friendship and Social Peace among Northern Migrants in Accra/Ghana. Legon Journal of Sociology Vol. 2 No.1:55-80.

Okamura, J. Y. (1983). Filipino Hometown Associations in Hawaii. Ethnology, Vol. 22, No. 4:341-353.

Orozco, M. (2006). Diasporas, Philanthropy and Hometown Associations: The Central American Experience. Draft (unpublished).

Orozco, M. and Rouse, R. (2007). Migrant Hometown Associations and Opportunities for Development: A Global Perspective. Inter-American Dialogue (February, 2007).

Owusu, Y. T. (2000). The Role of Ghanaian Immigrant Associations in Toronto, Canada. International Migration Review. Vol. 34, No. 4: 1155-1181.

Peil, M. (1974). Ghana's Aliens. International Migration Review, Vol. 8, No. 3, International Migration in Tropical Africa. pp. 367-381. 
Pojmann, w. (2007). Organizing Women Migrants: The Philipino and Cape Verdean Women's Associations in Rome. Migration Letters, Vol. 4, No. 1:29-39.

Population Reference Bureau-PRB (2006). World Population Data Sheet 2006. Available at: www.prb.org

Portes, A., C. Escobar and A. W. Radford (2007). Immigrant Transnational Organizations and Development: A Comparative Study. International Migration Review Vol. 41, Number 1:242-281.

Rouch, J. (1954). Migration in the Gold Coast. Accra. (Mimeographed).

Sardinha, J. (undated). Cape Verdean Associations in the Metropolitan Area of Lisbon: Their Role in Integration. Sussex Migration Working Paper No. 26, Sussex Centre for Migration Research.

Silva, J. (2006). Engaging Diaspora Communities in Development: An Investigation of Filipino Hometown Associations in Canada. Masters of Public Policy Thesis to the Faculty of Arts and Social Sciences, Simon Fraser University (unpublished).

Skinner, E. P. (1960). Labour Migration and Its Relationship to Socio-Cultural Change in Mossi

Society. Africa, Vol. 30, No. 4:375-401.

Stapleton, G. B. (1979). Nigerians in Ghana. West Africa, XLIII, No. 2184 (21): 177.

Twumasi-Ankrah, K. (1995). Rural-Urban Migration and Socioeconomic Development in Ghana: Some Discussions. Journal of Social Development in Africa, Vol. 10, No. 2:1322.

Twum-Baah, K. A. (2005). Volume and Characteristics of International Ghanaian Migration'. In

Takyiwaa Manuh (ed.) At Home in the World?: International Migration and Development in Contemporary Ghana and West Africa. Accra: Sub-Saharan Publishers.

University of Ghana (2005). Annual Report. University of Ghana, Legon. (2004). Annual Report. University of Ghana, Legon. 